\title{
Novobiocin inhibits membrane synthesis and vacuole formation of Enterococcus faecalis protoplasts
}

\author{
Rintaro Tsuchikado ${ }^{1, \#}$, Satoshi Kami ${ }^{1, \#}$, Sawako Takahashi ${ }^{1}$ and Hiromi Nishida ${ }^{1, *}$ \\ ${ }^{1}$ Department of Biotechnology, Toyama Prefectural University, Japan. \\ \# Equal contribution. \\ * Corresponding Author: \\ Hiromi Nishida, PhD, Department of Biotechnology, Toyama Prefectural University, 5180 Kurokawa, Imizu, Toyama 939-0398, Japan; \\ Phone: +81-766-56-7500; Fax: +81-766-56-2498; E-mail: hnishida@pu-toyama.ac.jp
}

\begin{abstract}
We demonstrate that plasma membrane biosynthesis and vacuole formation require DNA replication in Enterococcus faecalis protoplasts. The replication inhibitor novobiocin inhibited not only DNA replication but also cell enlargement (plasma membrane biosynthesis) and vacuole formation during the enlargement of the $E$. faecalis protoplasts. After novobiocin treatment prior to vacuole formation, the cell size of $E$. faecalis protoplasts was limited to $6 \mu \mathrm{m}$ in diameter and the cells lacked vacuoles. When novobiocin was added after vacuole formation, E. faecalis protoplasts grew with vacuole enlargement; after novobiocin removal, protoplasts were enlarged again. Although cell size distribution of the protoplasts was similar following the $24 \mathrm{~h}$ and $48 \mathrm{~h}$ novobiocin treatments, after $72 \mathrm{~h}$ of novobiocin treatment there was a greater number of smaller sized protoplasts, suggesting that extended novobiocin treatment may inhibit the re-enlargement of $E$. faecalis protoplasts after novobiocin removal. Our findings demonstrate that novobiocin can control the enlargement of $E$. faecalis protoplasts due to inhibition of DNA replication.
\end{abstract}

doi: $10.15698 /$ mic2020.11.735

Received originally: 09.02.2020;

in revised form: 01.07.2020,

Accepted 29.07.2020,

Published 10.08.2020.

Keywords: bacterial

protoplasts/spheroplasts, DNA replication, Enterococcus faecalis, novobiocin, plasma membrane synthesis, vacuole formation.

\section{Abbreviations:}

$\mathrm{Cq}$-quantification cycle, qPCR - quantitative $P C R$.

\section{INTRODUCTION}

DNA replication is essential for cell division in normally dividing bacterial cells (native forms) [1] and affects both cell morphology and cell division [2-4]. It has been reported that the bacterial chromosome DNA attaches to the plasma membrane [5-10] although cell division does not occur in bacterial protoplasts or spheroplasts in the presence of an inhibitor of peptidoglycan biosynthesis [11-14]; removal of the peptidoglycan synthetic inhibitor can induce recovery from Escherichia coli spheroplasts to their native forms [15-17]. However, spheroplasts can enlarge in Difco Marine Broth (DMB) containing a peptidoglycan biosynthesis inhibitor, for example, penicillin [18-21], and interestingly, DNA replication has been reported during protoplast or spheroplast enlargement $[13,14,18,19,23]$. In the protoplasts of the gram-positive lactic acid bacterium Enterococcus faecalis, the amount of DNA increased during the protoplast enlargement between 0 and $96 \mathrm{~h}$ of incubation [23]. In addition, when the DNA replication inhibitor novobiocin was added to the medium after $24 \mathrm{~h}$ of incubation, the $E$. faecalis protoplast enlargement, as well as DNA replication was inhibited. Direct injection of DNA into spheroplasts that are larger than $15 \mu \mathrm{m}$ in diameter also leads to vacuole formation [13, 14, 22, 23].

The bacterial cell division cycle may have several checkpoints [24-26]; although bacterial protoplasts do not divide, they can enlarge. Therefore, during protoplast enlargement, the bacterial cell division checkpoints of the native forms cannot function. In this study, we measured the increase in E. faecalis protoplast size and DNA amount, and also added novobiocin at different incubation times to test its effects. Without novobiocin treatment, E. faecalis protoplasts form vacuoles that also expand during the protoplast enlargement [23]. In this study, we focused on the relation between vacuole formation and the DNA replication.

\section{RESULTS}

Both DNA replication and cell enlargement of $E$. faecalis protoplasts stopped at $120 \mathrm{~h}$ of incubation

We measured the amount of $E$. faecalis chromosomal DNA by using real-time quantitative PCR (qPCR). The quantifica- 

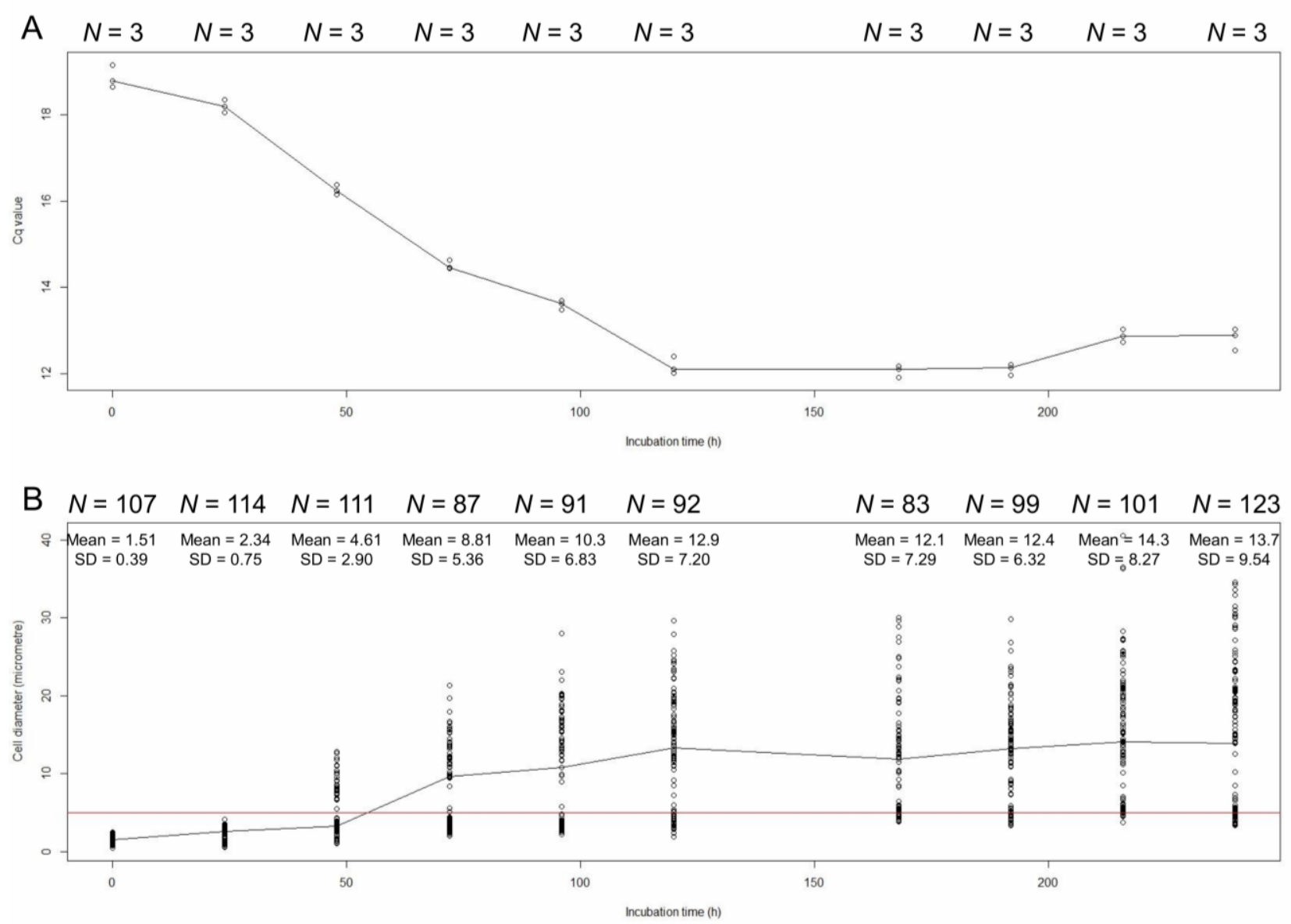

FIGURE 1: Cq values (A) and cell diameters (mm; B) of $E$. faecalis protoplasts at $0,24,48,72,96,120,168,192,216$, and $240 \mathrm{~h}$ of incubation. We used dnaA for qPCR. The red line indicates that the diameter of cells is $5 \mu \mathrm{m}$.

tion cycle $(\mathrm{Cq})$ value decreases with increasing DNA concentration. qPCR showed that the $\mathrm{Cq}$ values decreased from $0 \mathrm{~h}$ to $120 \mathrm{~h}$ of incubation of $E$. faecalis protoplasts in DMB plus penicillin (Fig. 1A, Table 1 upper part). Cell diameters increased with $0 \mathrm{~h}$ to $120 \mathrm{~h}$ of incubation (Fig. 1B, Table 1 lower part). The $\mathrm{Cq}$ values and cell diameters at $120,168,192,216$, and $240 \mathrm{~h}$ of incubation did not significantly $(p>0.05)$ differ (Tables 1 and 2). The DNA replication and cell enlargement of $E$. faecalis protoplasts stopped at $120 \mathrm{~h}$ of incubation in DMB containing penicillin, with no further significant change in DNA amount and cell size.

\section{Novobiocin inhibits DNA replication without degradation}

We compared DNA concentration of mitomycin C-treated protoplasts and novobiocin-treated protoplasts. The DNA amount was measured using real-time qPCR with two primer sets that amplified $d n a A$ near the replication initiation site and parC near the termination site [23]. The result indicated that the DNA concentration of novobiocintreated protoplasts was between those of control protoplasts at $24 \mathrm{~h}$ and $48 \mathrm{~h}$ of incubation (Fig. 2). On the other hand, the DNA concentration of mitomycin C-treated protoplasts was below that of control protoplasts at $0 \mathrm{~h}$ of incubation (Fig. 2). These results indicate that mitomycin C degraded the $E$. faecalis chromosomal DNA but novobiocin did not (Fig. 2). The DNA degradation by mitomycin $C$ was reported $[27,28]$.

Novobiocin treatment between 24 and $48 \mathrm{~h}$ of incubation increases the number of cells with a diameter of $>5 \mu \mathrm{m}$ without vacuoles

We showed that novobiocin treatment inhibited the E. faecalis protoplast enlargement [23]. Here, we investigated the effect of novobiocin treatment at different incubation times on the protoplast enlargement. Without novobiocin treatment (control), the cell diameters of E. faecalis protoplasts showed a peak between 3 and $4 \mu \mathrm{m}$ at 96,120 , and $144 \mathrm{~h}$ of incubation (the first row in Fig. 3 ). The cell diameter distributions following novobiocin treatment for 48 and $72 \mathrm{~h}$, and 72 and $96 \mathrm{~h}$ (the third and fourth rows in Fig. 3, respectively) were similar to that seen in case of the control. However, the cell diameter distribution following novobiocin treatment for 24 and $48 \mathrm{~h}$ (the second row in Fig. 3) peaked between 5 and $6 \mu \mathrm{m}$ (shown with arrows in Fig. 3) at 120, 144, and $168 \mathrm{~h}$ of incubation.

Next, we compared cells of $E$. faecalis protoplasts at $120 \mathrm{~h}$ of incubation without novobiocin treatment (the first row and the second column in Fig. 3) and those of $144 \mathrm{~h}$ of 
TABLE 1. Pairwise comparisons of novobiocin treatment.

Pairwise comparisons of Cq values using $t$ test with non-pooled SD ( $p$ value adjustment by Bonferroni).

\begin{tabular}{|c|c|c|c|c|c|c|c|c|c|}
\hline & $\mathrm{Oh}$ & $24 \mathrm{~h}$ & $48 \mathrm{~h}$ & $72 \mathrm{~h}$ & $96 \mathrm{~h}$ & $120 \mathrm{~h}$ & $168 \mathrm{~h}$ & $192 \mathrm{~h}$ & $216 h$ \\
\hline $24 \mathrm{~h}$ & 1 & & & & & & & & \\
\hline $48 \mathrm{~h}$ & 0.03843 & 0.00435 & & & & & & & \\
\hline $72 \mathrm{~h}$ & 0.00977 & 0.00042 & 0.00221 & & & & & & \\
\hline $96 \mathrm{~h}$ & 0.00637 & 0.0002 & 0.0004 & 0.02576 & & & & & \\
\hline $120 \mathrm{~h}$ & 0.00033 & 0.00017 & 0.00189 & 0.01182 & 0.06034 & & & & \\
\hline $168 \mathrm{~h}$ & 0.00148 & 4.10E-05 & 0.00013 & 0.00104 & 0.00646 & 1 & & & \\
\hline $192 \mathrm{~h}$ & 0.00241 & $5.30 \mathrm{E}-05$ & 8.00E-05 & 0.00069 & 0.00446 & 1 & 1 & & \\
\hline $216 \mathrm{~h}$ & 0.00152 & $7.50 \mathrm{E}-05$ & 0.00048 & 0.0075 & 0.15061 & 0.4254 & 0.10069 & 0.11339 & \\
\hline $240 h$ & 0.00039 & 0.00162 & 0.01579 & 0.1158 & 0.9473 & 1 & 0.84134 & 1 & \\
\hline
\end{tabular}

Pairwise comparisons of cell diameters using $t$ test with non-pooled SD ( $p$ value adjustment by Bonferroni).

\begin{tabular}{|c|c|c|c|c|c|c|c|c|c|}
\hline & $\mathrm{Oh}$ & $24 \mathrm{~h}$ & $48 h$ & $72 \mathrm{~h}$ & $96 \mathrm{~h}$ & $120 \mathrm{~h}$ & $168 \mathrm{~h}$ & $192 \mathrm{~h}$ & $216 \mathrm{~h}$ \\
\hline $24 \mathrm{~h}$ & $<2 \mathrm{E}-16$ & & & & & & & & \\
\hline $48 h$ & $<2 \mathrm{E}-16$ & 3.70E-11 & & & & & & & \\
\hline $72 \mathrm{~h}$ & $<2 \mathrm{E}-16$ & $<2 \mathrm{E}-16$ & $4.80 \mathrm{E}-08$ & & & & & & \\
\hline $96 \mathrm{~h}$ & $<2 \mathrm{E}-16$ & $<2 \mathrm{E}-16$ & $9.40 \mathrm{E}-10$ & 1 & & & & & \\
\hline $120 \mathrm{~h}$ & $<2 \mathrm{E}-16$ & $<2 \mathrm{E}-16$ & $<2 \mathrm{E}-16$ & 0.0014 & 0.6284 & & & & \\
\hline $168 \mathrm{~h}$ & $<2 \mathrm{E}-16$ & $<2 \mathrm{E}-16$ & $1.20 \mathrm{E}-12$ & 0.0463 & 1 & 1 & & & \\
\hline $192 \mathrm{~h}$ & $<2 \mathrm{E}-16$ & $<2 \mathrm{E}-16$ & $<2 \mathrm{E}-16$ & 0.0021 & 1 & 1 & 1 & & \\
\hline $216 h$ & $<2 \mathrm{E}-16$ & $<2 \mathrm{E}-16$ & $<2 \mathrm{E}-16$ & $6.30 \mathrm{E}-06$ & 0.0129 & 1 & 1 & 1 & \\
\hline $240 h$ & $<2 \mathrm{E}-16$ & $<2 \mathrm{E}-16$ & $<2 \mathrm{E}-16$ & 0.0002 & 0.1207 & 1 & 1 & 1 & 1 \\
\hline
\end{tabular}

incubation with novobiocin treatment (the second, third, and fourth rows and the second column in Fig. 3). The number of cells with vacuoles was 15 ( $23 \%$ of 65 cells), five (9.3\% of 54 cells), six ( $5.7 \%$ of 106 cells), and eight ( $13 \%$ of 63 cells), in $120 \mathrm{~h}$ incubation-protoplasts without novobiocin treatment, $144 \mathrm{~h}$ incubation-protoplasts with 24 to 48 $\mathrm{h}$ novobiocin treatment, $144 \mathrm{~h}$ incubation-protoplasts with 48 to $72 \mathrm{~h}$ novobiocin treatment, and $144 \mathrm{~h}$ incubationprotoplasts with 72 to $96 \mathrm{~h}$ novobiocin treatment, respectively (Table 2). In addition, the number of cells with a diameter of $>5 \mu \mathrm{m}$ without vacuoles was one $(1.5 \%$ of 65 cells), 29 ( $54 \%$ of 54 cells), four (3.8\% of 106 cells), and zero ( $0 \%$ of 63 cells), in $120 \mathrm{~h}$ incubation-protoplasts with- out novobiocin treatment, $144 \mathrm{~h}$ incubation-protoplasts with 24 to $48 \mathrm{~h}$ novobiocin treatment, $144 \mathrm{~h}$ incubationprotoplasts with 48 to $72 \mathrm{~h}$ novobiocin treatment, and 144 $\mathrm{h}$ incubation-protoplasts with 72 to $96 \mathrm{~h}$ novobiocin treatment, respectively (Table 2 ).

Novobiocin treatment duration influences protoplast enlargement in the presence of novobiocin and reenlargement after novobiocin removal

Here, the effect of novobiocin treatment time on E. faecalis protoplasts after novobiocin removal was investigated. Comparison among cell size distributions at the same incubation times including the time of novobiocin 

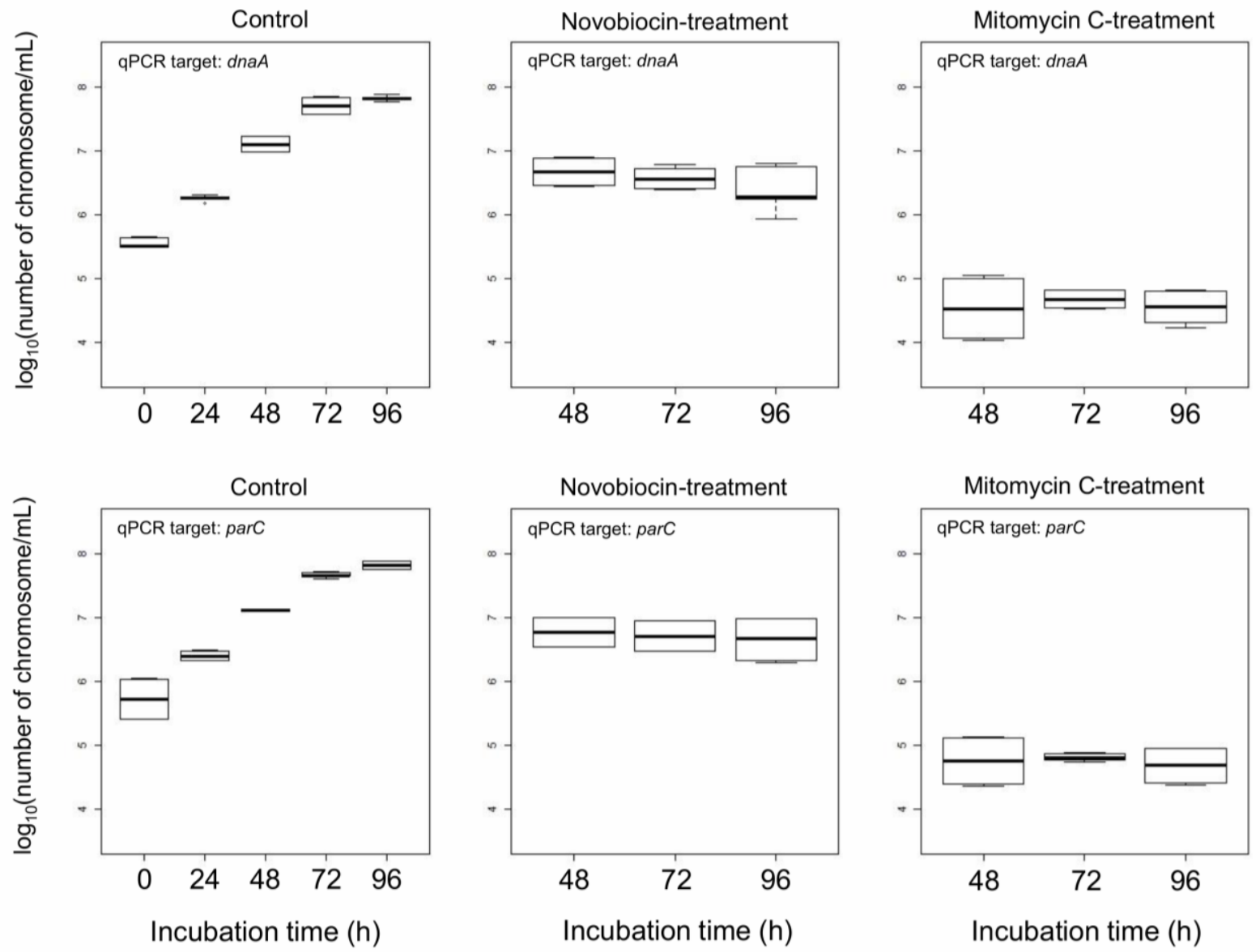

FIGURE 2: Boxplot of DNA concentration of $E$. facalis protoplasts. Control protoplasts were not treated by any DNA replication inhibitors. Mitomycin C or novobiocin was added at $24 \mathrm{~h}$ of incubation. After that, mitomycin C- and novobiocin-treated protoplasts were used at 48 (24 h-treatment), 72 (48 h-treatment), and $96 \mathrm{~h}$ (72 h-treatment) of incubation. Each experiment was performed with 8 replicates.

treatment, for example, $120 \mathrm{~h}$ (24-96 h novobiocin), $120 \mathrm{~h}$ (24-72 h novobiocin), and $120 \mathrm{~h}$ (24-48 h novobiocin), as shown in in Fig. 4, demonstrates that an extended novobiocin treatment time leads to a smaller cell size. Kolmogorov-Smirnov test showed that the cell size distribution at $120 \mathrm{~h}$ (24-72 h novobiocin) was significantly different $(p<0.05)$ from that at $120 \mathrm{~h}(24-96 \mathrm{~h}$ novobiocin $)$ and that at $120 \mathrm{~h}$ (24-48 $\mathrm{h}$ novobiocin). Therefore, cell enlargement was inhibited by the novobiocin treatment.

Comparison between cell size distributions at the same incubation time with different novobiocin treatments, for example, $120 \mathrm{~h}$ (24-48 h novobiocin), $144 \mathrm{~h}$ (24-72 h novobiocin), and $168 \mathrm{~h}$ (24-96 h novobiocin), as shown in Fig. 4, also indicates that the longer the novobiocin treatment duration, the smaller the cell size. However, the cell size distribution at $144 \mathrm{~h}$ (24-72 h novobiocin) was significantly different $(p<0.05)$ from that at $168 \mathrm{~h}(24-96 \mathrm{~h}$ novobiocin) but not $(p>0.05)$ from that at $120 \mathrm{~h}(24-48 \mathrm{~h}$ novobiocin). In addition, the cell size distribution at $144 \mathrm{~h}$ (24-48 h novobiocin) was not significantly different from that at $168 \mathrm{~h}$ (24-72 $\mathrm{h}$ novobiocin). These results indicate that the cell size distribution was not significantly different between the cells treated with novobiocin for $24 \mathrm{~h}$ and those treated with novobiocin for $48 \mathrm{~h}$.

When $E$. faecalis protoplasts were incubated for $168 \mathrm{~h}$ with two novobiocin treatments (24-48 $\mathrm{h}$ and 72-96 h), the cell size distribution (Fig. 5) was similar to that of $144 \mathrm{~h}$ (24-48 h novobiocin) of Fig. 4. Kolmogorov-Smirnov testing showed that the cell size distribution of $168 \mathrm{~h}(24-48 \mathrm{~h}$ and 72-96 h novobiocin) was not significantly different ( $p>$ $0.05)$ from that of $144 \mathrm{~h}$ ( $24-48 \mathrm{~h}$ novobiocin). Thus, the cell size distribution of $168 \mathrm{~h}$ incubation with two separated novobiocin treatments has a peak between 5 and $6 \mu \mathrm{m}$ (Fig. 5), indicating that the time of novobiocin treatment does not influence the cell enlargement.

\section{DISCUSSION}

In our previous study, we measured the amount of $E$. faecalis DNA and cell size between 0 and $96 \mathrm{~h}$ of incubation with novobiocin [23]. However, it was uncertain when the enlargement of the $E$. faecalis protoplasts stopped. This study demonstrates that DNA replication and cell enlargement of $E$. faecalis protoplasts stopped at the same time, at $120 \mathrm{~h}$ of incubation in DMB containing penicillin (Fig. 1), and suggests that plasma membrane biosynthesis requires 

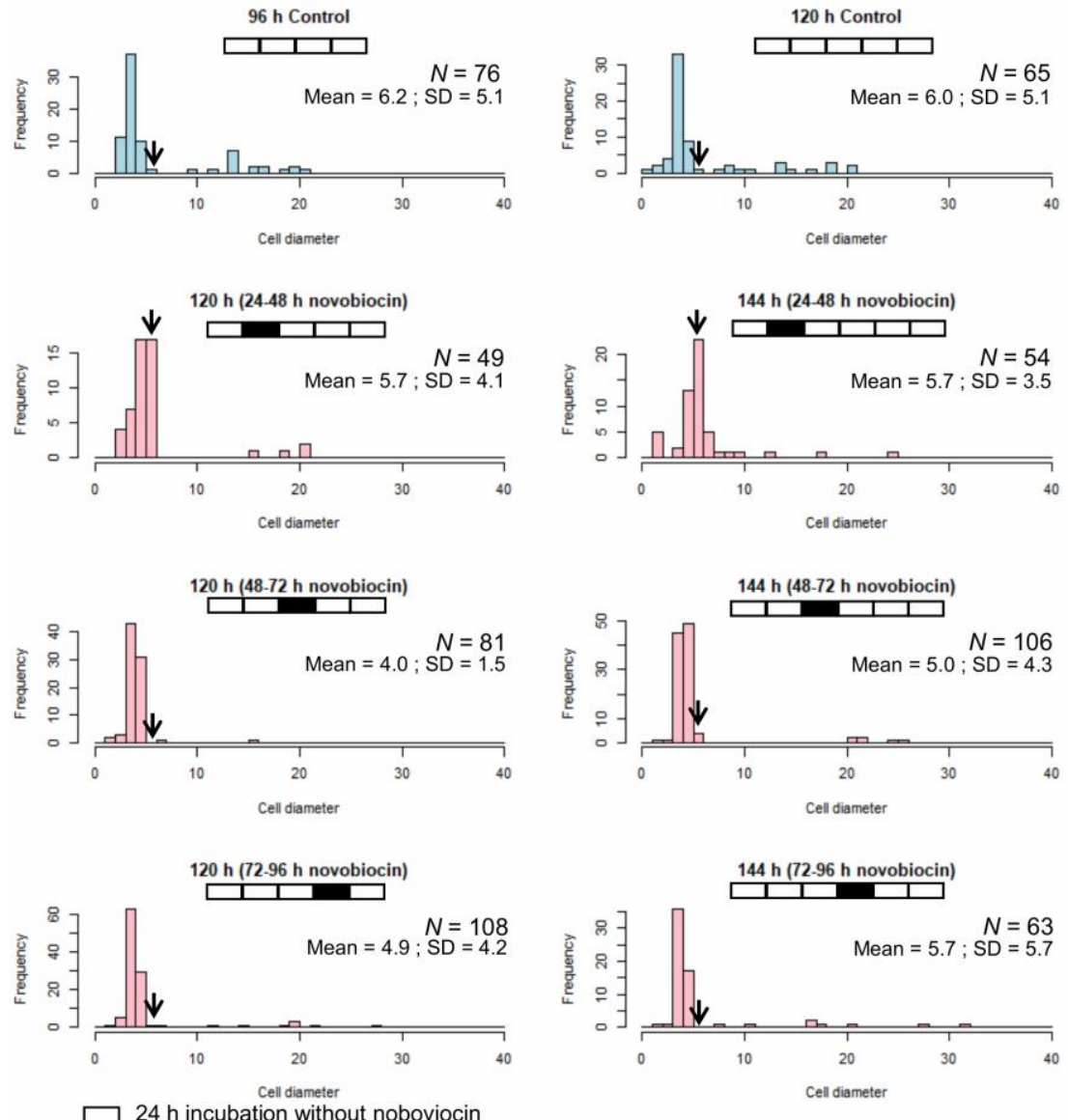

$144 \mathrm{~h}$ Control
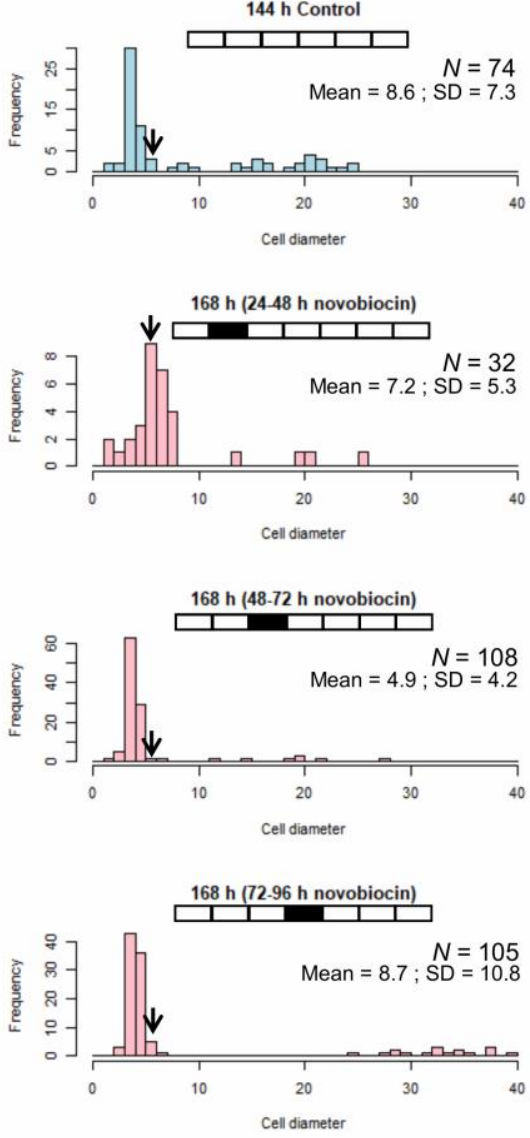

$24 \mathrm{~h}$ incubation with noboviocin

FIGURE 3: Size distribution of the control E. faecalis protoplast cells and E. faecalis protoplast cells treated with novobiocin for $24 \mathrm{~h}$. Arrows indicate the fraction of cells with a diameter between 5 and $6 \mu \mathrm{m}$.

DNA replication. We have shown that lipid composition changed during enlargement of Deinococcus grandis spheroplasts [21], indicating that membrane biosynthesis occurs in enlargement. In the native forms of bacteria, DNA replication should occur before the cell division; bacterial protoplasts, however, cannot divide in the presence of penicillin. In the presence of penicillin, Escherichia coli forms bulges at sites where the new cell wall is normally formed [2]. This bulge formation also requires DNA replication [2] and is consistent with our findings. It is likely that there is a mechanism that connects DNA replication and plasma membrane biosynthesis, which we do not yet know. Although more work is needed to elucidate how DNA replication and plasma membrane biosynthesis are connected, the bacterial protoplast enlargement system is a highly useful tool for the studies.

TABLE 2. Number of cells with vacuoles and cells with a diameter of $>5 \mu \mathrm{m}$ without vacuoles.

\begin{tabular}{lccccc}
\hline Cell type & $\begin{array}{l}120 \\
\text { without novobiocin }\end{array}$ & $\begin{array}{l}\mathbf{h} \text { incubation } \\
\text { with } \\
\text { ocin }\end{array}$ & $54-48$ incubation novobi- & $\begin{array}{l}144 \\
\text { with 48-72 h novobi- } \\
\text { ocin }\end{array}$ & $\begin{array}{l}\text { incubation } \\
\text { with } \\
\text { ocin }\end{array}$ \\
\hline Cells with vacuoles & $15(23.1 \%)$ & $6(5.7 \%)$ & $8(12.7 \%)$ \\
\hline $\begin{array}{l}\text { Cells with a diameter } \\
\text { of }>5 \mu \mathrm{m} \text { without } \\
\text { vacuoles }\end{array}$ & $1(1.5 \%)$ & $29(53.7 \%)$ & $4(3.8 \%)$ & $0(0.0 \%)$ \\
\hline Others & $49(75.4 \%)$ & $20(37.0 \%)$ & $96(90.6 \%)$ & $55(87.3 \%)$ \\
\hline Total & $65(100 \%)$ & $54(100 \%)$ & $106(100 \%)$ & $63(100 \%)$ \\
\hline
\end{tabular}


In this study, we used novobiocin as an inhibitor of DNA replication. Novobiocin inhibits DNA supercoiling catalyzed by DNA gyrase [29, 30]. Following novobiocin addition to $E$. faecalis protoplasts at $24 \mathrm{~h}$ incubation in DMB containing penicillin, the cell enlargement is strongly inhibited, but the cells are alive, lack vacuoles, and grow very slowly [23]. The cell size distribution of the $E$. faecalis protoplasts with novobiocin treatment between 24 and $48 \mathrm{~h}$ of incubation was unique with a peak of 5-6 $\mu \mathrm{m}$ (Fig. 3) at 96, 120, and $144 \mathrm{~h}$ of incubation.

Usually, during E. faecalis protoplast enlargement, cells with a diameter of $>5 \mu \mathrm{m}$ are observed after $48 \mathrm{~h}$ of incubation (Fig. 1B), all of which have vacuoles [23]. However, the number of cells with vacuoles is the lowest in case of the $E$. faecalis protoplasts that were treated with novobiocin for 24-48 $\mathrm{h}$. This suggests that vacuole formation cannot occur after removal of novobiocin from protoplasts treated with novobiocin for 24-48 h, but some plasma membrane biosynthesis can still occur and the cells with a diameter of $>5 \mu \mathrm{m}$ without vacuoles are observed. If protoplasts form vacuoles before $24 \mathrm{~h}$, they may continue to form vacuoles after novobiocin removal. This is consistent with the fact that a limited number of enlarged protoplasts with vacuoles were found in $E$. faecalis protoplasts with novobiocin treatment between 48 and $72 \mathrm{~h}$, and between 72 and $96 \mathrm{~h}$ (Table 2). These results suggest that vacuole formation requires DNA replication as well as plasma membrane biosynthesis, which may be related to the fact that plasma membrane endocytosis occurred at the early stage of the vacuole formation [13]. We have recently reported that bacterial plasma and vacuolar membranes were synchronously biosynthesized with differences depending on the bacterial species [31], strongly suggesting that DNA replication may be associated with vacuole formation as well as plasma membrane synthesis.

E. faecalis protoplasts enlarge very slowly in the presence of novobiocin [23]. Comparison of cell size distributions among the protoplasts with the same incubation times before different novobiocin treatment times showed that the longer the novobiocin treatment duration, the smaller the cell size (Fig. 4). This indicates that the rate of enlargement following novobiocin removal is faster than that in the presence of novobiocin. In addition, comparison of cell size distributions among the protoplasts with the same incubation times after different novobiocin treatment times also showed that the longer the novobiocin treatment, the smaller the cell size (Fig. 4). This suggests that the increase in the duration of novobiocin treatment may inhibit the re-enlargement of the E. faecalis protoplasts after novobiocin removal or results in a greater amount of time being required to reset the cell system.
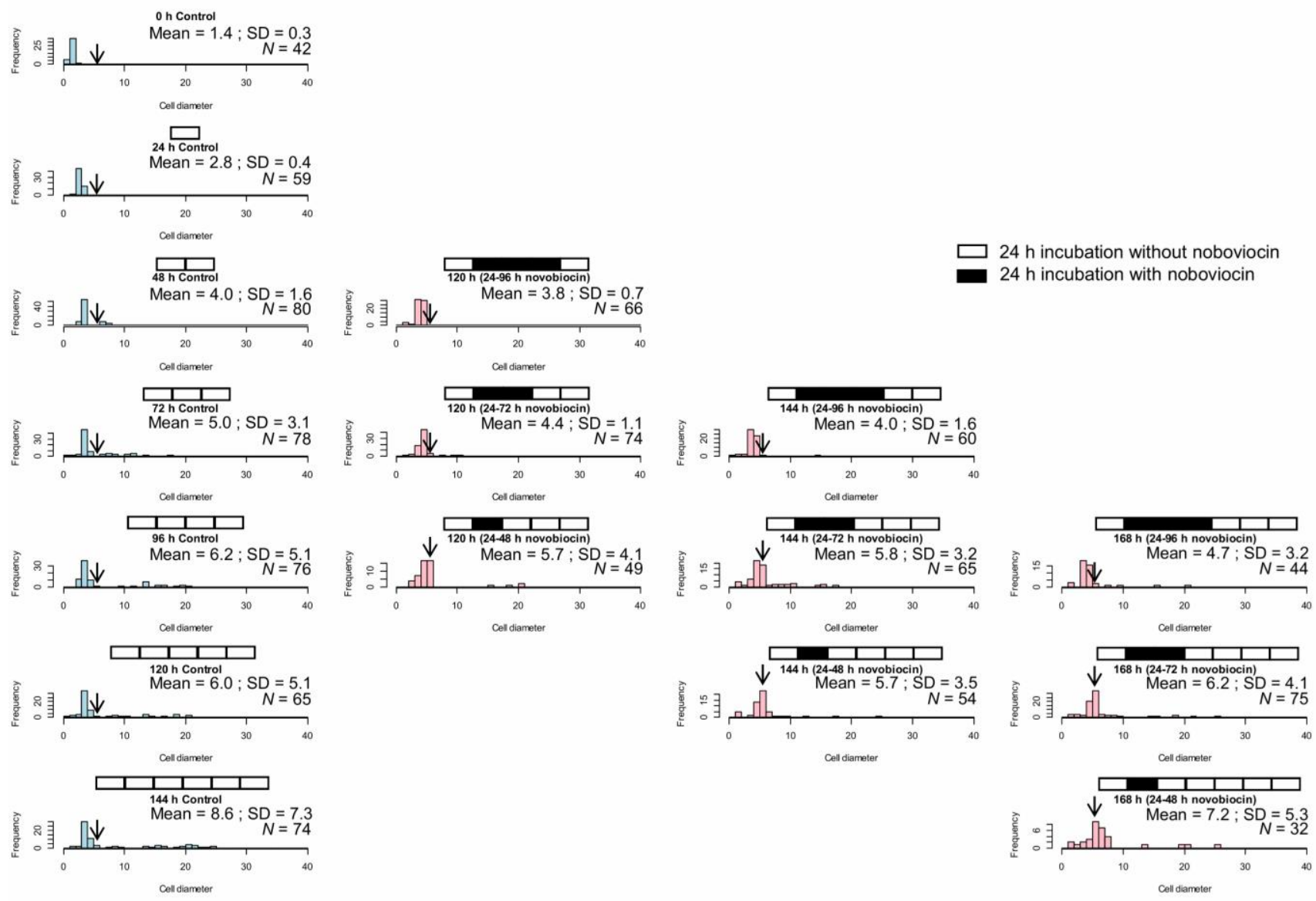

FIGURE 4: Size distribution of control E. faecalis protoplast cells and E. faecalis protoplast cells treated with novobiocin for different time periods $(\mathbf{2 4}, \mathbf{4 8}$, and $\mathbf{7 2} \mathrm{h})$. The arrows indicate the fraction of cells with a diameter between 5 and $6 \mu \mathrm{m}$. 

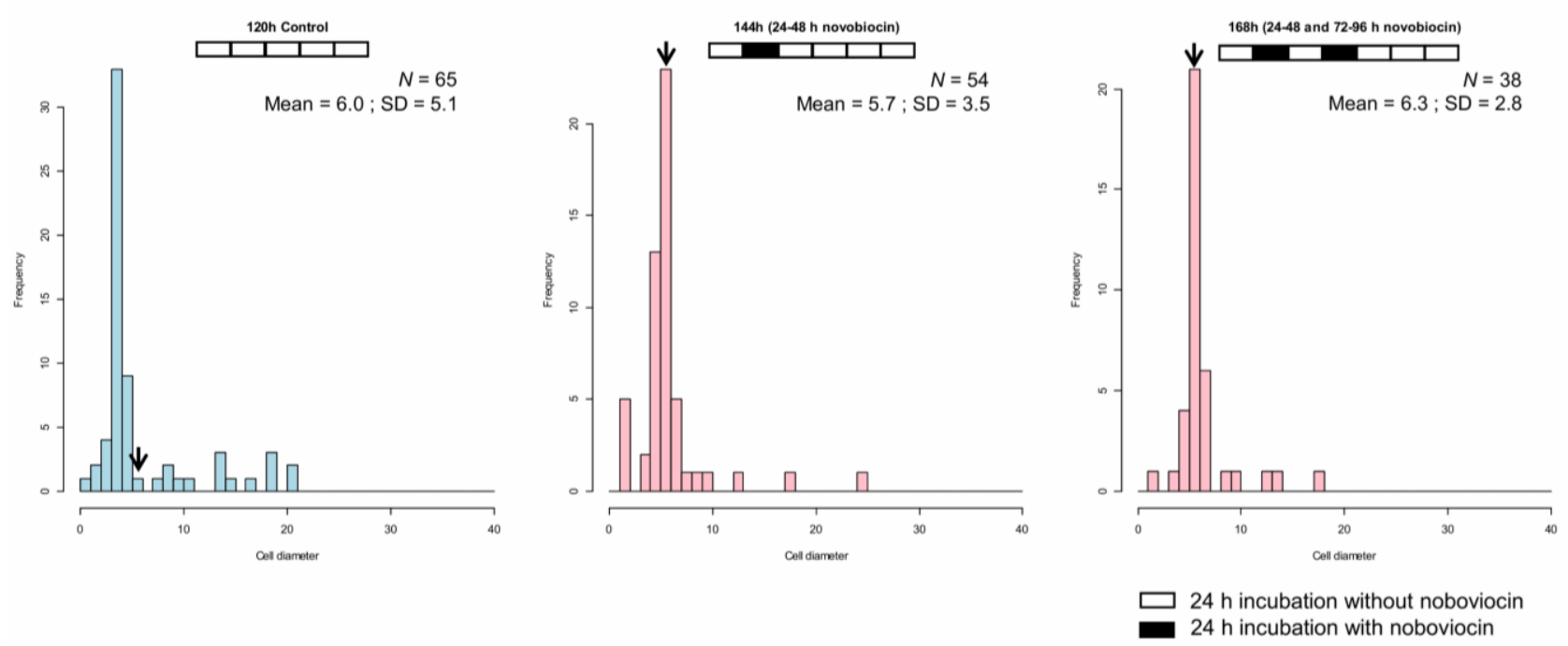

FIGURE 5: Cell size distribution of E. faecalis protoplast cells treated twice with novobiocin. The arrows indicate the fraction of cells with a diameter between 5 and $6 \mu \mathrm{m}$.

DNA replication-dependent vacuole formation may play the role of a checkpoint for the $E$. faecalis protoplast enlargement. Although untreated protoplasts without vacuoles are up to $5 \mu \mathrm{m}$ in diameter, the cell size of the novobiocin treated protoplasts without vacuoles is up to $6 \mu \mathrm{m}$ in diameter demonstrating unchecked enlargement as novobiocin inhibits DNA replication-dependent plasma membrane biosynthesis. In our laboratory, we have microinjected DNA or proteins to enlarged bacterial protoplasts, but we have not yet controlled these protoplast conditions [31]. In the near future, we will be able to control the protoplast cell size using novobiocin.

\section{MATERIALS AND METHODS}

\section{Preparation and culture of protoplasts}

E. faecalis NBRC 100480 was cultivated and protoplasts were prepared as previously described [23]. The protoplasts were centrifuged at $7000 \mathrm{rpm}$ for $5 \mathrm{~min}$ and resuspended in DMB $(5 \mathrm{~g} / \mathrm{L}$ peptone, $1 \mathrm{~g} / \mathrm{L}$ yeast extract, $0.1 \mathrm{~g} / \mathrm{L}$ ferric citrate, 19.45 $\mathrm{g} / \mathrm{L} \mathrm{NaCl}, 5.9 \mathrm{~g} / \mathrm{L} \mathrm{MgCl}_{2}, 3.24 \mathrm{~g} / \mathrm{L} \mathrm{MgSO}_{4}, 1.8 \mathrm{~g} / \mathrm{L} \mathrm{CaCl}_{2}, 0.55 \mathrm{~g} / \mathrm{L}$ $\mathrm{KCl}, 0.16 \mathrm{~g} / \mathrm{L} \mathrm{NaHCO}, 0.08 \mathrm{~g} / \mathrm{L} \mathrm{KBr}, 34 \mathrm{mg} / \mathrm{L} \mathrm{SrCl}_{2}, 22 \mathrm{mg} / \mathrm{L}$ $\mathrm{H}_{3} \mathrm{BO}_{3}, 8 \mathrm{mg} / \mathrm{L} \mathrm{Na}_{2} \mathrm{HPO}_{4}, 4 \mathrm{mg} / \mathrm{L} \mathrm{Na}{ }_{2} \mathrm{SiO}_{3}, 2.4 \mathrm{mg} / \mathrm{L} \mathrm{NaF}$, and $1.6 \mathrm{mg} / \mathrm{L} \mathrm{NH}_{4} \mathrm{NO}_{3}$ [BD, Franklin Lakes, NJ]) containing $300 \mu \mathrm{g} / \mathrm{mL}$ penicillin $\mathrm{G}$. The resulting suspension $(5 \mu \mathrm{L})$ was diluted with $1 \mathrm{~mL}$ of DMB containing $300 \mu \mathrm{g} / \mathrm{mL}$ penicillin $\mathrm{G}$ (Wako, Osaka) and incubated at $24^{\circ} \mathrm{C}$.

\section{Quantitative PCR (qPCR)}

DNA was extracted from the culture $(1 \mathrm{~mL})$ and purified using a NucleoSpin Tissue XS kit (Macherey-Nagel GmbH \& Co. KG, Düren). From the resulting $15 \mu \mathrm{L}$ of each DNA solution, $1 \mu \mathrm{L}$ was used for qPCR amplification for dnaA and parC [23]. DNA was amplified with FastStart Essential DNA Green Master kit (Roche, Basel) on a LightCycler Nano system (Roche). qPCR was performed at $95^{\circ} \mathrm{C}$ for $600 \mathrm{~s}$ followed by 45 cycles of denaturation $\left(95^{\circ} \mathrm{C}\right.$ for $\left.10 \mathrm{~s}\right)$, annealing $\left(55^{\circ} \mathrm{C}\right.$ for $\left.10 \mathrm{~s}\right)$, and extension $\left(72^{\circ} \mathrm{C}\right.$ for $\left.15 \mathrm{~s}\right)$. After extension, a melting curve analy- sis was performed from $60^{\circ} \mathrm{C}-95^{\circ} \mathrm{C}$ at $0.1^{\circ} \mathrm{C} / \mathrm{s}$ to confirm that nonspecific products had not been generated. The $\mathrm{Cq}$ values were obtained using LightCycler Nano software (Roche). The $\mathrm{Cq}$ values were estimated by pairwise $t$ test using the statistical software R.

\section{Cell size measurement}

Phase-contrast microscopy images of the protoplasts were obtained using an Olympus CKX41 (Tokyo). The cell sizes were measured using cellSens Standard 1.11 imaging software (Olympus, Tokyo). The cell sizes were estimated by pairwise $t$ test and Kolmogorov-Smirnov test using the statistical software R (https://www.r-project.org/).

\section{Novobiocin treatment}

Novobiocin (Wako, Osaka) was added to the incubation medium at 24,48 , and $72 \mathrm{~h}$ at a final concentration of $50 \mu \mathrm{g} / \mathrm{mL}$. It was not added to the control. We removed novobiocin from the incubation medium at 48,72 , and $96 \mathrm{~h}$, respectively. Then, we determined the cell enlargement and measured the cell size at 120,144 , and $168 \mathrm{~h}$ of incubation. Cultures were incubated in novobiocin for 48 and $72 \mathrm{~h}$ by adding novobiocin at the $24 \mathrm{~h}$ timepoint and then removing novobiocin at 72 and 96 $h$, respectively.

When an addition of novobiocin was performed twice, novobiocin was first added at a final concentration of $50 \mu \mathrm{g} / \mathrm{mL}$ at the $24 \mathrm{~h}$ time point; novobiocin was then removed from the incubation medium at $48 \mathrm{~h}$. Novobiocin was added a second time at $72 \mathrm{~h}$ and finally removed at $96 \mathrm{~h}$. Cell enlargement was determined by measuring the cell size at $168 \mathrm{~h}$ of incubation. Novobiocin removal was performed by 50 -fold dilution using filtered DMB containing penicillin.

\section{Mitomycin C treatment}

Mitomycin C (Sigma) was added to the incubation medium at $24 \mathrm{~h}$ at a final concentration of $25 \mu \mathrm{g} / \mathrm{mL}$. It was not added to the control. 


\section{ACKNOWLEDGMENTS}

We thank Taku Oshima and anonymous reviewers for valuable comments. This work was supported by JSPS KAKENHI grant number JP 18J20258.

\section{CONFLICT OF INTEREST}

The authors declare to have no conflict of interest.

\section{COPYRIGHT}

(C) 2020 Tsuchikado et al. This is an open-access article released under the terms of the Creative Commons Attribu-

\section{REFERENCES}

1. Helmstetter CE, and Pierucci O (1968). Cell division during inhibition of deoxyribonucleic acid synthesis in Escherichia coli. J Bacteriol 95: 1627-1633. doi: 10.1128/JB.95.5.1627-1633.1968

2. Schwarz U, Asmus A, and Frank H (1969). Autolytic enzymes and cell division of Escherichia coli. J Mol Biol 41: 419-429. doi: 10.1016/00222836(69)90285-X

3. Hill NS, Kadoya R, Chattoraj DK, and Levin PA (2012). Cell size and the initiation of DNA replication in bacteria. PLOS Genet 8: e1002549. doi: 10.1371/journal.pgen.1002549

4. Wallden M, Fange D, Lundius EG, Baltekin Ö, and Elf J (2016). The synchronization of replication and division cycles in individual $E$. coli cells. Cell 166: 729-739. doi: 10.1016/j.cell.2016.06.052

5. Marvin DA (1968). Control of DNA replication by membrane. Nature 219: 485-486. doi: 10.1038/219485a0

6. Sueoka N, and Quinn WG (1968). Membrane attachment of the chromosome replication origin in Bacillus subtilis. Cold Spring Harb Symp Quant Biol 33: 695-705. doi: 10.1101/sqb.1968.033.01.078

7. Earhart CF, Tremblay GY, Daniels MJ, and Schaechter M (1968). DNA replication studied by a new method for the isolation of cell membrane-DNA complexes. Cold Spring Harb Symp Quant Biol 33: 707-710. doi: 10.1101/sqb.1968.033.01.079

8. Leibowitz PJ, and Schaechter M (1975). The attachment of the bacterial chromosome to the cell membrane. Int Rev Cytol 41: 1-28. doi: 10.1016/S0074-7696(08)60964-X

9. Garner J, and Crooke E (1996). Membrane regulation of the chromosomal replication activity of $E$. coli DnaA requires a discrete site on the protein. EMBO J 15: 3477-3485. doi: 10.1002/j.14602075.1996.tb00714.x

10. Boeneman K, and Crooke E (2005). Chromosomal replication and the cell membrane. Curr Opin Microbiol 8: 143-148. doi: 10.1016/j.mib.2005.02.006

11. Lederberg J, and St Clair J (1958). Protoplasts and L-type growth of Escherichia coli. J Bacteriol 75: 143-160. doi: 10.1128/JB.75.2.143160.1958

12. Kusaka I (1967). Growth and division of protoplasts of Bacillus megaterium and inhibitor of division by penicillin. J Bacteriol 94: 884888. doi: 10.1128/JB.94.4.884-888.1967

13. Kuroda T, Okuda N, Saitoh N, Hiyama T, Terasaki $Y$, Anazawa H, Hirata A, Mogi T, Kusaka I, Tsuchiya T, and Yabe I (1998). Patch clamp studies on ion pumps of the cytoplasmic membrane of Escherichia coli. J Biol Chem 273: 16897-16904. doi: 10.1074/jbc.273.27.16897

14. Nakamura K, Ikeda S, Matsuo T, Hirata A, Takehara M, Hiyama T, Kawamura F, Kusaka I, Tsuchiya T, Kuroda T, and Yabe I (2011). Patch clamp analysis of the respiratory chain in Bacillus subtilis. Biochim Biophys Acta 1808: 1103-1107. doi: 10.1016/j.bbamem.2011.01.006 tion (CC BY) license, which allows the unrestricted use, distribution, and reproduction in any medium, provided the original author and source are acknowledged.

Please cite this article as: Rintaro Tsuchikado, Satoshi Kami, Sawako Takahashi and Hiromi Nishida (2020). Novobiocin inhibits membrane synthesis and vacuole formation of Enterococcus faecalis protoplasts. Microbial Cell 7(11): 300-308. doi: 10.15698/mic2020.11.735

15. Ranjit DK, and Young KD (2013). The Rcs stress response and accessory envelope proteins are required for de novo generation of cell shape in Escherichia coli. J Bacteriol 195: 2452-2462. doi: 10.1128/JB.00160-13

16. Ranjit DK, Jorgenson MA, and Young KD (2017). PBP1B glycosyltransferase and transpeptidase activates play different essential roles during the de novo regeneration of rod morphology in Escherichia coli. J Bacteriol 199: e00612-16. doi: 10.1128/JB.00612-16

17. Tabata KV, Sogo T, Moriizumi Y, and Noji H (2019). Regeneration of Escherichia coli giant protoplasts to their original form. Life 9: 24. doi: 10.3390/life9010024

18. Takahashi S, and Nishida H (2015). Quantitative analysis of chromosomal and plasmid DNA during the growth of spheroplasts of Esch erichia coli. J Gen Appl Microbiol 61: 262-265. doi: 10.2323/jgam.61.262

19. Takayanagi A, Takahashi S, and Nishida H (2016). Requirement of dark condition for enlargement of the aerobic anoxygenic photosynthetic marine bacterium Erythrobacter litoralis. J Gen Appl Microbiol 62: 14-17. doi: 10.2323/jgam.62.14

20. Takahashi S, and Nishida $\mathrm{H}$ (2017). Comparison of gene expression among normally divided cells, elongated cells, spheroplasts at the beginning of growth, and enlarged spheroplasts at $43 \mathrm{~h}$ of growth in Lelliottia amnigena. Gene Rep 7: 87-90. doi: 10.1016/j.genrep.2017.02.005

21. Nishino K, Morita $\mathrm{Y}$, Takahashi $\mathrm{S}$, Okumura M, Shiratani $\mathrm{S}$, Umemura K, Narumi I, Kondo C, Ochiai R, Oshima T, and Nishida $\mathrm{H}$ (2018). Enlargement of Deinococcus grandis spheroplasts requires $\mathrm{Mg}^{2+}$ or $\mathrm{Ca}^{2+}$. Microbiology 164: 1361-1371. doi: 10.1099/mic.0.000716

22. Takahashi S, Takayanagi A, Takahashi Y, Oshima T, and Nishida H (2016). Comparison of transcriptomes of enlarged spheroplasts of Erythrobacter litoralis and Lelliottia amnigena. AIMS Microbiol 2: 152-189. doi: 10.3934/microbiol.2016.2.152

23. Kami S, Tsuchikado R, and Nishida H (2019). DNA replication and cell enlargement of Enterococcus faecalis protoplasts. AIMS Microbiol 5: 347-357. doi: 10.3934/microbiol.2019.4.347

24. Autret S, Levine A, Holland IB, and Séror SJ (1997). Cell cycle checkpoints in bacteria. Biochimie 79: 549-554. doi: 10.1016/S03009084(97)82002-0

25. Grainge I (2010). FtsK - a bacterial cell division checkpoint? Mol Microbiol 78: 1055-1057. doi: 10.1111/j.1365-2958.2010.07411.x

26. Modell JW, Kambara TK, Perchuk BS, and Laub MT (2014). A DNA damage-induced, SOS-independent checkpoint regulates cell division in Caulobacter crescentus. PLOS Biol 12: e1001977. doi: 10.1371/journal.pbio.1001977 
27. Reich E, Shatkin AJ, Tatum EL (1960) Bacteriocidal action of mitomycin C. Biochim Biophys Acta 45: 608-610. doi: 10.1016/00063002(60)91504-3

28. Reich E, Shatkin AJ, Tatum EL (1961) Bacteriocidal action of mitomycin C. Biochim Biophys Acta 53: 132-149. doi: 10.1016/00063002(61)90800-9

29. Gellert M, O'Dea MH, and Tomizawa J (1976). Novobiocin and coumermycin inhibit DNA supercoiling catalyzed by DNA gyrase. Proc Natl Acad Sci USA 73: 4474-4478. doi: 10.1073/pnas.73.12.4474
30. Sugino A, Higgins NP, Brown PO, Peebles CL, and Cozzarelli NR (1978). Energy coupling in DNA gyrase and the mechanism of action of novobiocin. Proc Natl Acad Sci USA 75: 4838-4842. doi: 10.1073/pnas. 75.10 .4838

31. Takahashi S, Mizuma M, Kami S, Nishida H (2020). Speciesdependent protoplast enlargement involves different types of vacuole generation in bacteria. Sci Rep 10: 8832. doi: 10.1038/s41598-02065759-7 